\section{THE IMAGE OF THE IDEAL MONARCH IN THE TALE OF DUODECAGON}

\author{
Kusuma Raksamani ${ }^{1}$
}

\begin{abstract}
A collection of Thai tales, derived from Persian Islam, narrates how the kings successfully deal with their ministers and subjects with their righteousness. In the narrative, the twelve-sided tomb of a king is discovered with the inscription of twelve stories, endowed with precepts and wise sayings on the art of ruling. This article discusses the Persian source of the work and analyses the content and theme of the story that mirrors the image of the ideal king in Thai culture and that of Persian Muslims as well. Also, the power of the constructive narrative is stressed in allowing stories to educate the reader or the listener.
\end{abstract}

I heard that in his moment of agony

Anushirawan said to Hurmuz:

"Be thoughtful of the poor

And concerned not only with your own well-being.

No one will be prosperous in your kingdom

If you are devoted only to your own welfare.

The wise dislike the shepherd's sleep

When the wolf is after the sheep.

Take care of the poor and needy

And remember that the king owes

\footnotetext{
${ }^{1}$ Professor Emeritus of Sanskrit and Thai, Silpakorn University, Bangkok, Thailand
}

his crown to the people.

The people are the roots and the king is the tree

And the tree depends on the roots. Do not hurt the people's heart. If you do, you unroot yourself." ("Boostan" in Najibullah 1963: 297)

In the anecdote, Anushirawan was the King of Persia who ruled the Sasanian Empire $^{2}$ from 531-579 A.D. Hurmuz or Hormizd IV was his son and his successor (reigning 579-590). Anushirawan is remembered as a great patron of culture and a man of a noble character. Because of his fame, the Arabs called him Kisra (in Arabic meaning "great") and also named all the rulers of the Sasanian Empire by this name. The name Kisra later became Khosrow which is well known in Western languages, and Anushirawan was called Khosrow I. His reputation for justice as well as wisdom is cited in several of wise sayings and stories. The above mentioned account of his last words to his successor Hurmuz, preaching on the role of a good monarch, is one of them.

The anecdote is in Boostan, a Persian collection of poems by Saadi of Shiraz, a great poet of ethical and humanitarian literature. Saadi (1219-1292) lived during the troubled period of the Mongol rule and the fall of Baghdad. ${ }^{3}$ As early as the last

\footnotetext{
${ }^{2}$ Sasanians or Sasanids were a Persian dynasty founded in 224 A.D. and dominated by Arabs during the years 637-651. The Sasanian Empire ruled over Mesopotamia, Persia, Western Turkestan and Afghanistan.

${ }^{3}$ After the death of Ghengis Khan in 1227 A.D. his vast Mongolian empire was divided up among his four sons. Hulagu, one of his grandsons, conquered Persian territory in 1256. He launched the Mongol assault on Baghdad in 1258 and founded the Empire of the Ilkhanids,
} 
decade of the $12^{\text {th }}$ century the literary works of the Islam culture, mostly in Arabic and Persian, were used to express messages other than simply the illustration of a story. Many manuscripts were provided with dedications intended to reflect the glory of ruling princes. They could also be used as lessons in kingship and statesmanship and, in many instances, served as ways of recollecting and interpreting contemporary events through references to past heroes. (Hattstein \& Delius 2004: 51-52). Saadi's is no exception. Saadi was attached to the courts of Atabek ben Saad Zangui, the ruler of Fars (southern Iran), and his descendants, to whom Saadi dedicated his works. Nevertheless, instead of flattering the important men of his time, as was customary among poets, he invited them to practise humility, justice and piety. $\mathrm{He}$ called the Boostan, which consists of ten chapters, "the Palace of Wealth, furnished with ten doors of instruction" (Iran Chamber Society: 4).The first one concerns justice, counsel and the administration of government. Also in Gulistan, his collection of stories in eight chapters, Saadi dedicates the first chapter to advice on the morals of kings. In his works, historical and legendary figures such as Anushirawan, Hurmuz, Faridun, Mahmud, Hatim Tay and Bahram are characterized in ethical and political parables or tales, interspersed with those wise sayings attributed to some of those sovereigns. Sir Edwin Arnold, an English poet and scholar of Eastern philosophy, has aptly described the Gulistan in culinary terms as "an intellectual pillaw [spiced rice]; a literary curry; a kebab [grilled meat] of versatile genius." (Yohannan 1956: 21)

who converted to Islam in 1295 . The

Mongolian dynasty on Persian territory was dissolved in 1335 .
Saadi tells us of his purpose in writing the Gulistan:

I have, in summary form, comprised in this book morals and choice tales, embellished with verses and meritorious deeds of Kings; in collecting materials for which, I have spent a considerable part of my life [...] my design was to give advice, and I have spoken accordingly. I committed the work to god, and departed.

(Gladwin 2000: 23)

His intention probably accords with those of Muslim thinkers and writers who believe that they have a duty to explain the noble values and present them in an easilyunderstood and attractive fashion so that people will be able to develop the values and attitudes which God intended for them, thus enabling them to enjoy a decent and pleasant life (Al-Hashimi 2003: 20). Saadi's works are, we may say, a unique combination of canonical and secular precepts. His narrative is mostly concerned with worldly activities, but his resolutions are well grounded in Muslim thought. In the preface to the Boostan (Iran Chamber Society: 3-4), apart from praise of God, he refers to Prophet Muhammad as his inspiration for ideal leadership:

Think not, O Saadi, That one can walk on the road of purity except in the footsteps of Muhammad.

$\mathrm{He}$ is the patriarch of the prophets, the guide of the path to salvation; the mediator of mankind, and the chief of the Court of Judgement.

What of thy praises can Saadi utter? 
The mercy of God be upon thee, O Prophet, and peace!

Again in the preface of the Gulistan (Gladwin 2000: 10), the qualities of the good leader are dedicated to Prophet Muhammad:

There is a tradition of the chief of created beings, the most noble of existences, the mercy of the universe, the purest of mankind and completion of the revolution of ages, Muhammad Mustafa ${ }^{4}$ (upon whom be blessings and peace!). The intercessor, the obeyed, the gracious prophet, the bountiful, the majestic, the affable, the sealed.

Saadi's Gulistan and Boostan are attractive to readers not only in Muslim circles but also in Western ones, through their Latin and English translations. Ralph Waldo Emerson said that Saadi "speaks to all nations, and like Homer, Shakespeare, Cervantes and Montaigne, is perpetually modern." Emerson found in the Gulistan "the universality of moral law." (Yohannan 1956: 21)

The meritorious deeds of Kings, in the disguise of Persian tales, travelled far away from home to the land of Siam. A court manuscript of a collection of Persian tales called Nithan Sip Song Liam (Tale of Duodecagon) is dated as early as the late Ayutthaya Period.

On the colophon of the oldest extant manuscript is this inscription:

\footnotetext{
${ }^{4}$ In Arabic, al-mustafa means "chosen one". It is one of the common names of Prophet Muhammad, as chosen by God.
}

I, Khun Kalayabodi, composed these exemplary tales dedicated to the King on Sunday, the fourth month, the tenth day of New Moon, 1114 Minor Era, the Year of Monkey and the Fourth-Ended Year.

The date falls in 1752 A.D., in the reign of King Baromakote (reigning 1732-1758) and the title of Khun Kalayabodi belonged to Muslim court officials, mostly Persian, in the late Ayutthaya through to the Ratanakosin Periods. Accordingly, it might not be wrong to conclude that the Nithan Sip Song Liam was written or, more precisely, compiled by a Persian Muslim court official in the reign of King Baromakote of Ayutthaya. As I have already discussed elsewhere (Raksamani 2004: 43-56), the Nithan Sip Song Liam is not a direct translation of any Persian work. It is a compilation of tales, legends and wise sayings related by Persian officials in the court of King Narai (reigning 1656-1688) and passed down by courtiers until written down by Khun Kalayabodi in the late Ayutthaya period.

One of the sources of these tales is Saadi's; at least three tales, (No.1 The Ailing King Who Needs a Child's Blood for Medication; No. 8 The King Who Fosters a Thief's Son; No. 9 The King Who Offers His Head for Alms) correspond to those in the Gulistan and the Boostan. Also, the analogy of the treeroots and the king-people as in King Anushirawan's words in the Boostan (see above) is recited in the Thai tale on the inscription of a king named Nowasawan, a Thai version of Nushirawan or Anushirawan. His son Horamuk, a Thai version of Hurmuz, also appears in the Thai tale. 
Although the Tale may "speak to all nations," according to Emerson, because of its "universality of moral law"; still, the names of characters, such as Hatim, Faridun, Wadinsa, Mansur, and settings, such as Mada'in, Busra, are unfamiliar to Thai readers. The words nithan khaek, given to the Tale by Prince Damrongrachanuphap (1963: a) may refer to its Persian (or khaek persia in Thai) source. Also, the word khaek implies the exotic flavour of the narrative and Schweisguth (1951: 137) refers to "les Douze Angles de la Perse" (the Twelve Sides from Persia) as "une littérature de caractère profane et de provenance exotique."

The exotic tale $e^{5}$ was set back in the time of King Mamun ${ }^{6}$ of Baghdad. The King is told that the body of the righteous King Nowasawan has been kept in a duodecagonal mausoleum ${ }^{7}$ on top of a

\footnotetext{
${ }^{5}$ The discussion is based on the text published by Khurusapha, when faced with lacunae the manuscript of Ayutthaya is consulted.

${ }^{6}$ Mamun was the king who ruled over Abbasid Empire between 813-833 A.D. He was known as a patron of knowledge who had the House of Wisdom (in Arabic, Baitul Hikmah) constructed in his kingdom. His father was Harun Al-Rashid (reigning 786-809), under whom came the political and cultural zenith. Harun is a character in The Thousand and One Nights or The Arabian Nights. For Thai readers, he is better known in Lilit Nithra Chakhrit (the Thai version of the Sleeper Awakened) as a king who loves adventures and often disguises himself to observe what irregularities are committed in his country.

${ }^{7}$ Mausoleums (elaborate and monumental tombs), that thrived in Central Asia in the $11^{\text {th }}$ and $12^{\text {th }}$ centuries, were the preserve of the sultan, his wives, the highest officers of the empire, the viziers, and certain important "men of faith", while "common mortals" were buried in cemeteries (Hattstein and Delius 2004: 374).
}

mountain in a deserted land. The mausoleum was constructed by Nowasawan's successor, King Horamuk, and inscribed with ethico-political rules, wise sayings and tales on good kingship and statesmanship. Before his own death, King Horamuk has the pathway to the mausoleum covered up in order that no one can disturb the corpse of his father. However, King Mamun finally finds the way to it. On the gate of the mausoleum, he sees a golden inscription describing five gems of human beings along with a specific form of nourishment and destruction for way of destroying each gem. The first gem is wisdom for which the nourishment is prudence and the destruction is ignorance. The second is knowledge, nourished with study and destroyed by negligence. The third is shame, nourished with self-esteem and destroyed by women. ${ }^{8}$ The fourth is justice, nourished with truth and destroyed by falsehood. The fifth is endurance, nourished with piety and destroyed by avarice. Metaphorically, gems are virtues such as wisdom, shame, and justice that are precious for a human being. To maintain them, we need certain qualities like prudence, self-esteem, truth, and piety. Meanwhile we should protect the virtues from damage such as ignorance, negligence, avarice and the like.

Having read the inscription, King Mamun enters the mausoleum. He sees the corpse of King Nowasawan sitting upright as if

The styles of mausoleums are varied: towershaped, domed or polygonal. In the Thai Tale, King Nowasawan's mausoleum is duodecagonal or twelve-sided. Thus the book is called Nithan Sip Song Liam (Tale of Duodecagon).

${ }^{8}$ As in a patriarchy, women are always blamed for being the cause of men's failure or misbehaviour. 
alive. He salutes the great King and changes the attire of the corpse. Then he sees, on the ruby veil over the corpse's face, the inscription of five rules: to eliminate sin, to assist dependents, to provide merit, to do good and to support people. Each of the right four fingers wears a ring, inscribed with the rules of governing: to be considerate in punishment, to concentrate on the wellbeing of people, to be conscious of transiency and to relieve people of their misery. The rings on the left four fingers read as follows: to be virtuous, to appoint intelligent people as the king's eyes and ears, to patronize religion and to be circumspect.

King Mamun learns many more ethical rules for a sovereign from the inscription on the ruby bracelets on both wrists and along the wall of the mausoleum. As he is circumambulating the mausoleum, he sees on each side of the duodecagonal wall the inscription of a tale narrating the story of the past king. Before leaving, the King has all the twelve tales and teachings in the inscription written down in a manuscript for himself. From then on he strictly follows this advice and eventually becomes a pious and righteous king, just like King Nowasawan.

The narrative of the Nithan Sip Song Liam is composed of two parts. The first is the prologue or the kathamukha, relating the story of King Mamun who is impressed by the righteousness of King Nowasawan through the inscription of ethical rules and wise sayings. The second is a collection of twelve stories narrating how the kings in the past dealt with their subjects and ministers and how they achieved success and happiness through their virtue. Each story ends with a phrase like this: "...his land then became peaceful because of his righteousness." The story is a somewhat elaborated and illustrated version of some rules or sayings in the prologue. For example, the advice of how not to oppress the subjects is the theme of at least two stories.

The first one narrates the story of King Faridun who suffers from a terrible disease. The court physicians advise him to take a child's blood for medication; otherwise he will die in three months. The King issues an order to search for a child whose parents are willing to trade him for a big piece of gold. A twelve-year old boy is brought. Being reluctant to shed the blood of his subjects, the King asks the court judges to reconsider it. They insist that the boy's life be taken for the survival of the King and that of the kingdom. When brought in to the King's presence, the boy laughs and says: "A son needs his parents' protection; still, my parents prefer gold to my life. People entrust fair judgment to the judge; yet the court judges decide to kill me. As a subject, I implore the King's mercy but he loves his life more than anything else. My last resort is then to complain to God who has created many kinds of diseases. He must have created the medication for curing them too but I wonder why the King's disease has no other cure except my blood." The King becomes troubled at these words. He tells his courtiers: "Even if I am cured by the boy's blood, finally I can't escape death. My fault will be rumoured and last forever. Whatever merit I have done will be tarnished by this mistake." He then gives the boy some wealth and releases him. Suddenly the disease is completely cured, just because of his righteousness.

The second story narrates the story of King Humayun of Busra who lost his way while hunting. He meets a pomegranate- 
grower and asks for some water to drink. The old man fetches him a bowl of pomegranate juice. When the King finds out that the man has earned much wealth from the plants, he considers collecting tax from the farmer. But when he asks for another bowl of juice, the farmer scarcely fills the bowl. The surprised King asks why, at first, a single pomegranate yielded a full bowl of juice but later even ten pomegranates can not make it. The old farmer replies that possibly the sovereign was considering the plant tax. When asked to clarify, he refers to an old saying "Much required will get less, but less required will get much." Then he explains that if farmers have much income extracted from them, they will not be willing to grow more plants and then the tax revenue will diminish. In contrast, low taxes will be an incentive for their planting and the tax revenue will increase. On his return to his palace, the King orders his men not to collect tax from those who have never been taxed before, and also reduces the tax usually collected. From then on, the court gains much more income and people live happily because the King has ruled over the land righteously.

In the prologue, there is a saying: "The king is like a physician and people are his patients who need to tell him their symptoms. If the former refuses to listen to the latter, how can the disease be cured?" This saying is further referred to King Suleiman who knew the language of animals and listened to an ant who complained to him. ${ }^{9}$ The theme of the

\footnotetext{
${ }^{9}$ In the Qur'an (Scripture of Islam), King Suleiman (Solomon) knew the language of animals. One day he heard an ant saying to its companions: "O ye ants, get into habitations, lest Solomon and his hosts crush you (under foot) without knowing it" (chapter 27: verse 18). Yusuf Ali (1977: 982 fn. 3258) in his
}

sovereign listening to his subjects is found in the story of King Nowasawan who allows his people to ring the bell, complaining to him. One day an emaciated mule comes to ring the bell by pulling the cord with its teeth. Having seen the starved animal, the King sends for its owner who later informs the King that the mule, when young, worked for him and was fed well in return; since the animal is too old to work, he has let it find food by itself. The king then reprimands the man and orders him to keep the animal and feed it well as before.

In the prologue, there is the advice for a sovereign to be considerate to his subjects. It says: "Be thoughtful; they came under your patronage because they are helpless."

commentary, explains: "The ant, to outward appearance, is a very small and humble creature. In the great pomp and circumstances of the world, she (generic feminine in Arabic) may be neglected or even trampled on by people who mean her no harm. Yet, by her wisdom, she carries on her own life within her own sphere ("habitation") unmolested, and make a useful contribution to the economy of the world. So there is room for the humblest people in the spiritual world." In the next verse (27: 19) King Suleiman smiled, amused at the ant's speech and then he prayed and vowed to God that he would work the righteousness that would please Him. Yusuf Ali (fn. 3259) here explains: "The counterpart to the position of the humble ant is the position of the great king like Suleiman. He prays that his power and wisdom and all other gifts may be used for righteousness and particularly for the benefit of all around him. The ant being in his thoughts, we may suppose that he means particularly in his prayer that he may not even unwillingly tread on humble being in his preoccupation with the great things of the world." To sum up, both the governor and the governed are significant in accordance with their own means; a consideration for each other is needed. 
The theme is found in the story of King Wadinsa who has a ruby ring made by his jeweller. The man accidentally breaks the gemstone into two pieces. He is scared to death and lives in distress for many days before the King summons him. When the king sees the gemstone in two pieces and the jeweller in distress, he is considerate to him. He says: "The ruby is divided into two pieces just as I want. At first, I would like to have had two rings made from the gemstone; but I didn't ask for that, lest it would trouble you. Now you have made it easy for me. Go and make me two ruby rings!" The jeweller is relieved and is released, no matter how the courtiers warn the King against him. The King tells his men: "The jeweller is a man of incomparable skill. To punish him with death is unwise; we will not only lose him but also lose our prestige. A king should be merciful to his people. The people are the bricks forming the foundation of the city wall; they should not be destroyed."

The stories of the kings in all twelve tales including interspersed precepts in the narrative of the Nithan Sip Song Liam form the mosaic image of an ideal king who is endowed with goodness. As is common among monarchical practices, some advice in the Tale such as selfsacrifice (บริจาค), angerlessness (อักโกธะ), non-oppressive- ness (อวิหิงสา) and nondeviation from righteousness (อวิโรธนะ) is found in the Ten Virtues of a Ruler (ทศพิธราชธรรม). Also from the Islamic perspective, as is evident in the Qur'an (Scripture of Islam) and the Sunna (Prophet Muhammad's model behaviour), freedom (al-huriyya, in Arabic), equality (musāwāt) and justice ('adl) are essential in the social and political context (Kamali 1999: 2-4).
The narrative also instructs ministers and courtiers on their behaviour towards the king. For example, the advice for the king to select good ministers as his eyes and ears, indirectly tells them how they can be included in the selection. The Tale even includes the role of subjects as another factor in government. The counterpart to the position of the great king is that of the humble subjects. They are humble but they make a useful contribution to the system. The metaphors of the roots of the tree and bricks forming the root of the city wall indicate the significance of the people. No wonder the Nithan Sip Song Liam had been noted as a court literary work in the first reign of the Ratanakosin down to the fourth.

In the first reign, there was a goldenlettered court manuscript of the Nithan Sip Song Liam. The colophon indicates that it was written in 1782 A.D., the year King Rama I ascended the throne. According to H.R.H. Prince Damrongrachanuphap, the Tale had been valued, since the Ayutthaya period, as an ethico-didactic story of rājadharma (or rājanīti, royal policy and statesmanship); thus the King preferred having a court copy available for him (Damrongrachanuphap 1963: a). In the third reign when "the People's University" was established at Wat Pho, the Nithan Sip Song Liam was one of the stories in the inscriptions of sciences and arts. As regards its content of sovereigns and their subjects, and also the wider popular access to the inscriptions, we may say that this was a means of instructing people how to behave as subjects of the sovereign. Evidently, the story was concerned not only with the rajjadharma but also the prajādharma (popular practical conduct). According to Ginsburg (1967: 7), in 1863 A.D. (in the reign of King Rama IV) Adolf 
Bastian $^{10}$ brought back to Germany the English translation of the Nithan Sip Song Liam and referred to it along with the other two tales, the Nithan Nang Tantrai and the Pisacapakarana ${ }^{11}$ in 1864 and again in 1873. The Nithan Sip Song Liam was first published in Thai by Dr. Samuel John Smith at his press at Bangkholaem in 1870 A.D. and sold at 75 satang a copy.

In the reign of King Rama VII, the Nithan Sip Song Liam was published as memorial books for distribution at cremation ceremonies and later compiled into volume together with other tales or pakaranas. H.R.H. Prince Damrongrachanuphap, who was in charge of the Royal Institute, states in his preface of the book (1963: d): "The title 'Sip Song Liam' is rather unattractive and conceals the significance of the work. Since the Tale is of Iranian [another name for Persian] origin and concerns royal practices or rachatham [räjadharma], the work is here renamed Nithan Iranrachatham." Unfortunately, the name Nithan Iranrachatham seems to have faded away from the Thai book circle; it was published together with other 5 pakaranas ${ }^{12}$ with the subtitle, Prachum Pakaranam (Collection of Tales) and today the volume remains unnoticed on the shelves of a few libraries. All the six tales in the Prachum Pakaranam prove the power of narrative. In the Vetalapakaranam, the tales are

\footnotetext{
${ }^{10}$ Adolf Bastian (1826-1905), a German ethnographer who travelled to many Asian countries and wrote books on their cultures and on Buddhism.

${ }^{11}$ Details on these 2 tales are in Kusuma III, 2004: 77-91.

${ }^{12}$ Vetalapakaranam is from the Vikramaditya story cycle; Nandukapakaranam, Paksipakaranam, Pisacapakaranam and Hitopadesavatthupakaranam - all the four are the Pancatantra recensions; details in Kusuma III, 2004: 77-166, 175-185.
}

meant to test the hero's righteousness and intelligence. In the Nithan Iranrachatham (Nithan Sip Song Liam) as well as the other four Pancatantra recensions, the narratives are meant for educating listeners, or a reader in the case of King Mamun, who are characters in the story. In the Pancatantra, four irresponsible and wayward princes are taught by a Brahmin the art of ruling in the disguise of stories. After this course of narrative education, the princes eventually become well-versed in political and ethical knowledge, ready to succeed to their father's throne. Likewise, the narrative in the Nithan Sip Song Liam educates King Mamun and persuades him to follow the right path of his forefather, King Nowasawan. In this case, the narrator is absent, leaving behind him the inscription of advice and the image of an ideal king. Both the four princes and King Mamun are educated through the constructive power of narrative. So are the many enthusiastic readers. But unluckily, today the power of narrative seems to be diminished for it has been hidden away on the bookshelf for too long.

\section{References}

Al-Hashimi, Muhammad Ali. 2003. The Ideal Muslim. Riyadh: International Islamic Publishing House.

Ali, A. Yusuf. 1977. The Glorious Qur'an. Indiana: The Muslim Students' Association of the United States and Canada.

Damrongrachanuphap, Prince. 1963. Explanation for Nithan Iranrachatham (อธิบายนิทานอิหร่านราชธรรม). In Nithan Iranrachatham: Collection of Tales 
(นิทานอิหร่านราชธรรม: ประชุมปกรณัม).

Bangkok: Khurusapha. (In Thai)

Ginsburg, Henry D. 1967. Thai Literary

Tales Derived from the Sanskrit

Tantropakhyana with Special

Reference to the Pisacapakaranam.

Master's Thesis, University of Hawaii.

Gladwin, Francis (tr.). 2000. The Gulistan or Rose Garden by Saadi. London: AlHoda.

Hattstein, Markus and Peter Delius. 2004. Islam Art and Architecture.

Konigswinter: Konemann.

Iran Chamber Society. Accessed 18 June 2008. The Boostan of Saadi. [Online]. Available: http://www.

iranchamber.com/literature/saadi/books /bostan_saadi.pdf

Kamali, Muhammad Hashim. 1999.

Freedom Equality and Justice in Islam. Selangor: Ilmiah Publishers.

Najibullah. 1963. Islamic Literature.

Washington: Washington Square Press.

Raksamani, Kusuma. 2004. Kusumawanna

III: Pakaranum Nithan (กุสุมาวรรณนา 3:

ปกรณัมนิทาน). Bangkok: Mae

Khanphang. (In Thai)

Schweisguth, P. 1951. Étude sur la littérature siamoise. Paris: Imprimérie nationale.

Yohannan, John D. 1956. A Treasury of Asian Literature. New York: The John Day Company. 